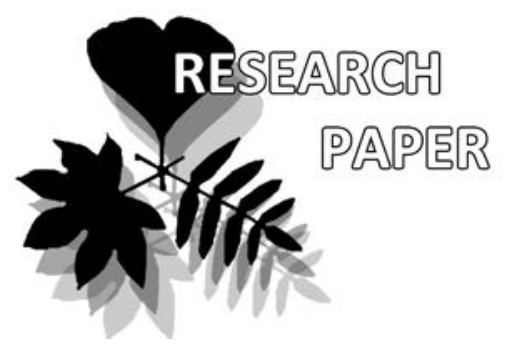

\title{
Genetic diversity of the endangered endemic species Hedysarum sangilense Krasnoborov et Timokhina (Fabaceae)
}

\author{
Inessa Y. Selyutina, Elena S. Konichenko*, Evgeniy G. Zibzeev \\ \& Irina N. Kuban
}

Inessa Y. Selyutina

e-mail: selyutina.inessa@mail.ru

Elena S. Konichenko*

e-mail: zundukii@rambler.ru

Evgeniy G. Zibzeev

e-mail: egzibzeev@gmail.com

Irina N. Kuban

e-mail: irinakuban@gmail.com

Central Siberian Botanical Garden SB RAS, Russia

* corresponding author

Manuscript received: 27.01.2021

Review completed: 25.04.2021

Accepted for publication: 05.05 .2021

Published online: 10.05 .2020

\begin{abstract}
A B S T R A C T
Hedysarum sangilense Krasnoborov et Timokhina (Fabaceae) is a rare subendemic species of the Fabaceae family. It has been found in a restricted area, only in isolated habitats in Tyva Republic and Northern Mongolia. Two PCR techniques, using RAPD and inter-simple sequence repeat (ISSR) markers, were used to perform a comparative analysis of genetic diversity in this species. When amplifying DNA with three RAPD primers, we produced 51 bands, of which $21(40.6 \%)$ were polymorphic. Amplification of genomic DNA using ISSR analysis vielded 96 fragments, of which $35(36.6 \%)$ were polymorphic. Nei,s gene diversity $(\mathrm{H})$ was estimated to be 0.105 within populations (range $0.086-0.150)$ and 0.191 at the species level. Genetic differentiation among populations (GST) was 0.383. The results indicate that both of the marker systems RAPD and ISSR, individually or in combination, can be effectively used in the determination of the genetic relationship among and within populations of $H$. sangilense.

K e y w o r d s : endangered species, genetic diversity, Hedysarum sangilense, ISSR, plant conservation, rare species, RAPD, subendemic
\end{abstract}

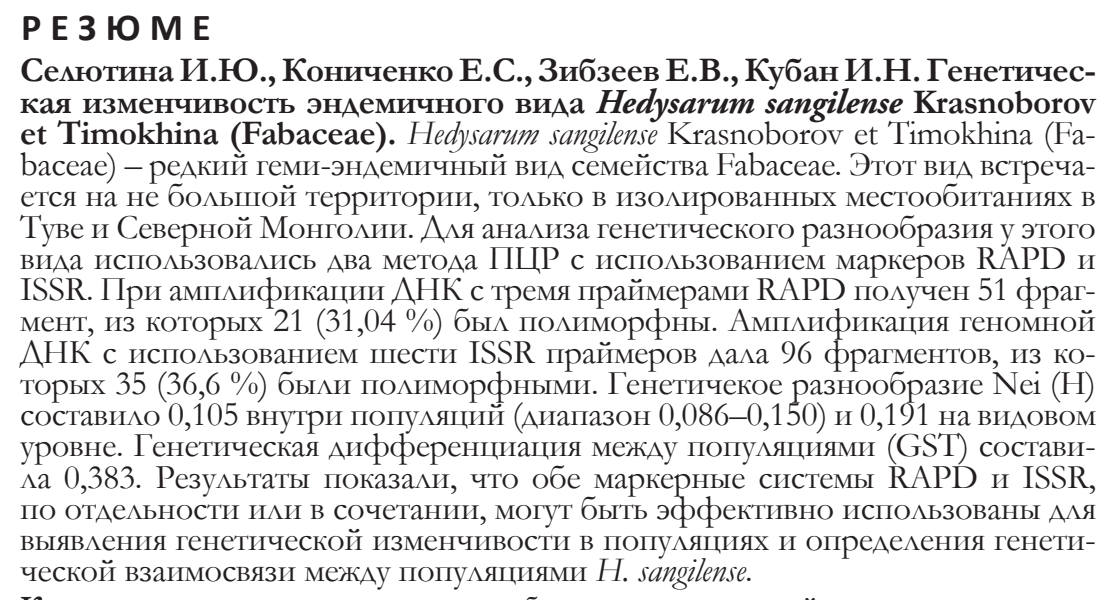

Кмючевые слова: генетическое разнообразие, охрана растений, редкие виды, эндемик, Hedysarum sangilense, ISSR, RAPD
Hedysarum sangilense Krasnob. (Fabaceae) is a rare subendemic plant of Tuva Republic and Northern Mongolia. This species has been found in restricted areas in isolated habitats. $H$. sangilense is a perennial plant that occurs on the Sangilen Plateau in alpine habitats, larch forests and riverbanks. The range of this Central Asian rock endemic is restricted to this plateau, which occupies the southeastern part of the Republic Tuva in Russia (Kurbatskii 1994). According to the herbarium label, $H$. sangilense is also found on the eastern Tannu-Ola Ridge and the surrounding areas of northern Mongolia (Krasnoborov \& Timokhina 1975, Ma lyshev \& Sobolevskaya 1980, Gunin et al. 1999, Urgamal et al. 2014).

The species Hedysarum sangilense Krasnob. et Timoch. was first described by Krasnoborov \& Timokhina (1975). This new species was different from all other species of the genus Hedysarum common in Siberia by morphological characteristics.

Six populations of $H$. sangilense have been studied from tundras of Kobresia myosuroides (Vill.) Fiori and Dryas oxyodonta Juz. on the highlands of the Sangilen Plateau, as well as from dwarf birch thickets with Betula fruticosa Pall. in the middle reaches of the Naryn River (Fig. 1).

$H$. sangilense populations on the Sangilen Plateau are restricted to a small area of few mountainous sites, severely restricting gene flow or seed dispersal among populations; all sites occur within a small geographic area. These factors increase the threat of extinction for the species.

Mountain habitats of Central Asia in the most continental areas experience extreme climatic conditions. Effects of habitat isolation should be especially pronounced where mountains rise from dry and cold highlands, such as the Sangilen Plateau. Steep topographic and therefore climatic gradients lead to heavily fragmented habitats, characterised by barriers to migration and genetic exchange. Levels of natural fragmentation are thus generally high, and several studies have demonstrated strong genetic effects and isolation by distance (Bauert et al. 1998, Schonswetter et al. $2002,2004)$. Effects of habitat isolation are especially pro- 


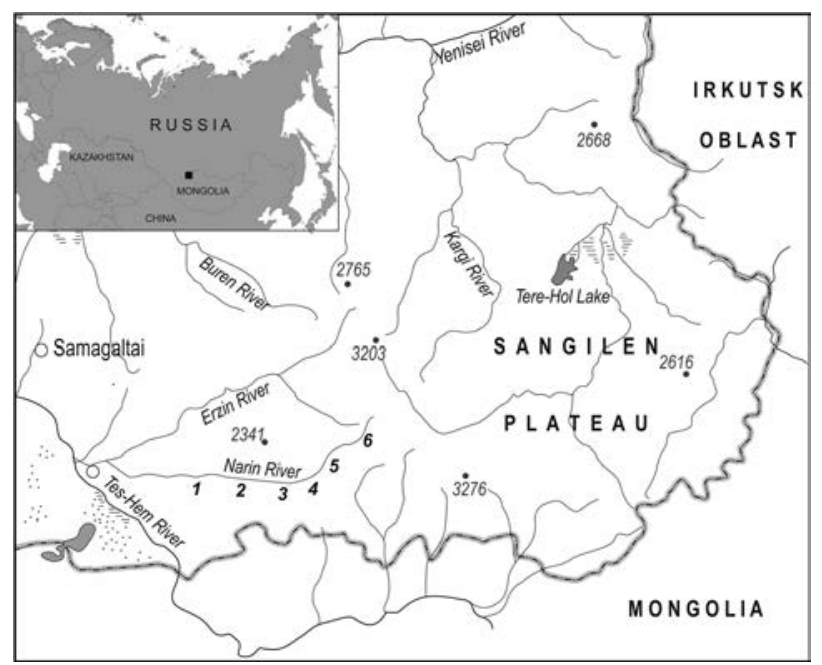

Figure 1 Map of the six Hedysarum sangilense Krasnoborov et Timokhina populations. See Table 1 for abbreviations.

nounced where mountains rise from dry lowlands, such as the Central Asian Gobi.

\section{MATERIAL AND METHODS}

Plant material. Hedysarum sangilense is a perennial herb $25-35 \mathrm{~cm}$ in height with a branched caudex; chromosome numbers are $2 \mathrm{n}=16+1 \mathrm{~B}, 2 \mathrm{n}=14$ (Flora Sibiriae 1994, Krasnikov \& Schaulo 2004).

Six populations of $H$. sangilense were investigated in this study, and in each of population, 16 to 18 individuals (total 104) were randomly sampled (Fig. 1, Table 1).

Plants were collected in June and July 2014. Population size ranged from 200 to $\sim 600$ individuals (Table 1). Distance between population varied from $1 \mathrm{~km}$ to up to several tens of $\mathrm{km}$; DNA was isolated from dry leaves. Equal amounts (0.09-0.12 g dry weight) of total genomic DNA were extracted according to the CTAB method described by Doyle \& Doyle (1987). The CTAB extraction buffer was used for DNA isolation, and DNA was precipitated by cold isopropanol.

RAPD and ISSR amplification. The DNA amplifications with each RAPD and ISSR primers were repeated at least twice to ensure reproducibility. The PCR amplifications were performed in a total reaction volume of $25 \mu \mathrm{l}$ containing $10 \mathrm{mM}$ Tris- $\mathrm{HCl}$ (pH 8.3), $50 \mathrm{mM} \mathrm{KCl}, 0.2 \mathrm{mM}$ each dNTP, $1.15 \mathrm{mM} \mathrm{MgCl}, 10 \mathrm{mM}$ primer, $1 \mathrm{U}$ of Tag polymerase and
30-50 ng of genomic DNA. The DNA amplifications were performed using a C 1000 Thermal Cycler (BioRad Laboratories, USA); amplification was conducted for 35 cycles. Each PCR cycle consisted of the following steps: $0.40 \mathrm{~min}$ at $94^{\circ} \mathrm{C}, 0.45 \mathrm{~min}$ at annealing temperature (Table 2), $1.30 \mathrm{~min}$ at $72^{\circ} \mathrm{C}$; an initial pre-denaturation step $\left(1.30 \mathrm{~min}\right.$ at $\left.94^{\circ} \mathrm{C}\right)$ and a final extension step $\left(5 \mathrm{~min}\right.$ at $\left.72^{\circ} \mathrm{C}\right)$ were added. For each primer, we determined the best annealing temperature by performing a gradient PCR. The PCR products were separated by electrophoresis on $1 \%$ agarose gel in $1 \times$ TBE buffer (50 mM Tris, $50 \mathrm{mM}$ boric acid, $2.5 \mathrm{mM}$ EDTA, pH 8.3) for $3 \mathrm{~h} 30 \mathrm{~min}$ at $100 \mathrm{~V}$ and detected by staining with bromphenol blue. Gels were stained with CYBR-Green (Medigen, Russia) and then photographed under UV light. The size of the amplified products was determined by comparison with a 100-bp molecular weight ladder (Medigen, Russia).

For all samples, PCR reactions were carried out using the same thermocycler. The gel images were identified using Bio-Rad GelDoc XR+.

Data analysis. The amplifications were independently repeated three times using the same procedure to ensure that the amplifications obtained with the primers were reproducible and consistent. The amplified bands were scored manually as 1 (present) and 0 (absent). A binary matrix was obtained by visual scoring of the bands in the cases of both RAPD and ISSR.

Data were analysed using the POPGENE software (version 1.31; Yeh et al. 1997) to estimate genetic diversity parameters: PPB (percentage of polymorphic loci), $A_{E}$ (the effective number of alleles per locus), $A_{O}$ (observed number of alleles per locus), $H_{E}$ (Nei's (1973) gene diversity). At the species level, genetic diversity measures $\left(\mathrm{H}_{\mathrm{T}}\right)$ and the level of gene flow $\left(\mathrm{N}_{\mathrm{M}}\right)$ were measured using Nei's gene diversity statistics; Nei's genetic distance between populations was computed using the same program (Nei 1972). Genetic diversity was estimated using Shannon's information measure (Lewinton 1972). To examine the genetic relationship at the species level, a dendrogram was constructed using UPGMA of the POPGENE software. We performed AMOVA, which partitions total phenotypic variance into within and among populations, using GENALEX v. 6.51 (Peakall \& Smouse 2012). To test the correlation between genetic distance and geographical distance among populations, a Mantel test was performed, computing 999 permutations.

Table 1. Sampling details of populations used in the present study.

\begin{tabular}{|c|c|c|c|c|c|c|c|}
\hline No & $\begin{array}{l}\text { Population } \\
\text { code }\end{array}$ & Locations & Coordinates & Altitude (m) & $\mathbf{N}^{\mathrm{A}}$ & Habitat & Community type \\
\hline 1 & NRN1 & $\begin{array}{l}\text { Plateau Sangilen, left bank } \\
\text { of the Naryn River }\end{array}$ & 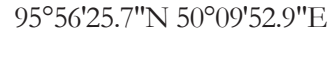 & 1530 & 200 & river valley & Larch forest after fire \\
\hline 2 & NRN 3 & $\begin{array}{l}\text { Plateau Sangilen, the left } \\
\text { bank of the Naryn River }\end{array}$ & $96^{\circ} 08^{\prime} 18.4^{\prime \prime} \mathrm{N} 50^{\circ} 08^{\prime} 42.3^{\prime \prime} \mathrm{E}$ & 1733 & 300 & river valley & $\begin{array}{l}\text { Thickets Betula fruticosa in } \\
\text { place of burned wood }\end{array}$ \\
\hline 3 & NRN 2 & $\begin{array}{l}\text { Plateau Sangilen, left bank } \\
\text { of the Naryn River }\end{array}$ & $96^{\circ} 10^{\prime} 11.2^{\prime \prime} \mathrm{N} 50^{\circ} 10^{\prime} 00.8^{\prime \prime} \mathrm{E}$ & 1740 & 200 & river valley & Thicket of Betula fruticosa \\
\hline 4 & SNG 4 & $\begin{array}{l}\text { Plateau Sangilen, the upper } \\
\text { Balik-Tig-Khem River }\end{array}$ & $96^{\circ} 18^{\prime} 20.5^{\prime \prime} \mathrm{N} 50^{\circ} 15^{\prime} 05.2^{\prime \prime} \mathrm{E}$ & 2408 & 200 & $\begin{array}{l}\text { rocky slope north- } \\
\text { west exposition }\end{array}$ & Dryas tundra \\
\hline 5 & SNG 3 & $\begin{array}{l}\text { Plateau Sangilen, the upper } \\
\text { Balik-Tig-Khem River }\end{array}$ & $96^{\circ} 19^{\prime} 35.4^{\prime \prime} \mathrm{N} 50^{\circ} 15^{\prime} 28.0^{\prime \prime} \mathrm{E}$ & 2497 & 200 & $\begin{array}{l}\text { rocky slope south } \\
\text { exposition }\end{array}$ & Dryas tundra \\
\hline 6 & SNG 2 & $\begin{array}{l}\text { Plateau Sangilen, the upper } \\
\text { Balik-Tig-Khem River }\end{array}$ & $96^{\circ} 28^{\prime} 12.9^{\prime \prime N} 50^{\circ} 19^{\prime} 17.6^{\prime \prime E}$ & 2375 & 600 & $\begin{array}{l}\text { rocky slope south- } \\
\text { west exposition }\end{array}$ & $\begin{array}{l}\text { Tundra (Kobresia } \\
\text { myosuroides) }\end{array}$ \\
\hline
\end{tabular}




\section{RESULTS}

Two independent methods, RAPD and ISSR, were applied to investigate the variability among the genotypes of Hedysarum sangilense.

In the case of ISSR, a set of 25 primers was used for screening of all accessions; of these, 6 produced clear and reproducible fragments, which were chosen for further analysis. A total of 96 replicated bands were present, of which 35 bands were found polymorphic, which amounted to a $36.6 \%$ polymorphism. The bands produced ranged from 10 to 18 per primer, with an average of 16 ; their size varied from 300 to $1500 \mathrm{bp}$ (Table 2).

Percentage polymorphism ranged from 0 to 100, with an average of 35.11 Shannon's information ranged from 0.099 to 0.310 , with a mean of 0.176 . Mean Nei's (1973) genetic diversity $(\mathrm{H})$ in populations was 0.124 (range from 0.066 to 0.202 ) and on the special level 0.189 (Table 3). Nei’s (1978) genetic distance between populations ranged from 0.061 to

Table 2. ISSR primers in this study and analysis of ISSR-generated banding patterns.

\begin{tabular}{|c|c|c|c|c|c|}
\hline Primers & $\begin{array}{l}\text { Sequence } \\
\text { 5' to } 3^{\prime}\end{array}$ & $\begin{array}{l}\text { Annealing } \\
\text { temperature } \\
\left({ }^{\circ} \mathrm{C}\right)\end{array}$ & $\begin{array}{l}\text { No. of } \\
\text { bands } \\
\text { scored }\end{array}$ & $\begin{array}{l}\text { No. of } \\
\text { polymorphic } \\
\text { bands }\end{array}$ & $P, \%$ \\
\hline \multicolumn{6}{|l|}{ RAPD } \\
\hline OPA 08 & GTGACGTAG $-<G>$ & 32 & 13 & 5 & 38.5 \\
\hline OPA 09 & GGGTAACGC $-<\mathrm{C}>$ & 34 & 20 & 9 & 45 \\
\hline OPA 20 & GTTGCGATC $-<\mathrm{C}>$ & 32 & 18 & 7 & 38.9 \\
\hline Average & & & 17 & 7 & 40.6 \\
\hline Total & & & 51 & 21 & \\
\hline \multicolumn{6}{|l|}{ ISSR } \\
\hline UBS 807 & $(\mathrm{AG})_{8} \mathrm{G}-<\mathrm{T}>$ & 53 & 17 & 5 & 29.4 \\
\hline UBS 834 & $(\mathrm{AG})_{-}^{8} \mathrm{GY}-<\mathrm{T}>$ & 55 & 14 & 5 & 35.7 \\
\hline UBS 835 & $(\mathrm{AG})_{7}^{7} \mathrm{G}-<\mathrm{A}>$ & 54 & 18 & 8 & 44.4 \\
\hline UBS 855 & (AC) ${ }_{8} \mathrm{CY}-<\mathrm{T}>$ & 60 & 14 & 6 & 42.8 \\
\hline UBS 857 & (CTC) ${ }_{3}-<\mathrm{C}>$ & 55 & 17 & 4 & 23.5 \\
\hline $99 B$ & $(\mathrm{CA})_{6} \mathrm{G}-<\mathrm{G}>$ & 42 & 16 & 7 & 43.7 \\
\hline Average & & & 16 & 5.8 & 36.6 \\
\hline Total & & & 96 & 35 & \\
\hline
\end{tabular}

Table 3. Genetic variability within populations of Hedysarum sangilense detected by RAPD and ISSR analyses.

\begin{tabular}{lllllll}
\hline Population & $\mathbf{A}_{\mathbf{O}}$ & $\mathbf{A}_{\mathbf{E}}$ & $\mathbf{I}$ & $\mathbf{H}$ & $\mathbf{P P B} \mathbf{( \% )}$ & $\mathbf{P r B}$ \\
\hline RAPD & & & & & & \\
NRN1 & 1.118 & 1.077 & 0.065 & 0.044 & 11.76 & 0 \\
NRN3 & 1.588 & 1.295 & 0.286 & 0.185 & 58.82 & 0 \\
NAR2 & 1.333 & 1.186 & 0.168 & 0.111 & 33.33 & 0 \\
SNG4 & 1.157 & 1.110 & 0.091 & 0.062 & 15.69 & 0 \\
SNG3 & 1.274 & 1.118 & 0.116 & 0.074 & 27.45 & 0 \\
SNG2 & 1.392 & 1.237 & 0.141 & 0.211 & 39.22 & 0 \\
Mean & 1.310 & 1.170 & 0.144 & 0.114 & 31.04 & 0 \\
Species level & 1.961 & 1.277 & 0.290 & 0.175 & 39.22 & 0 \\
ISSR & & & & & & \\
NRN1 & 1.184 & 1.112 & 0.099 & 0.066 & 18.45 & 4 \\
NRN3 & 1.388 & 1.238 & 0.210 & 0.140 & 38.83 & 6 \\
NAR2 & 1.621 & 1.326 & 0.310 & 0.202 & 62.14 & 14 \\
SNG4 & 1.320 & 1.176 & 0.105 & 0.160 & 32.04 & 4 \\
SNG3 & 1.233 & 1.138 & 0.123 & 0.082 & 23.30 & 1 \\
SNG2 & 1.359 & 1.149 & 0.150 & 0.095 & 35.92 & 3 \\
Mean & 1.351 & 1.190 & 0.176 & 0.124 & 35.11 & 5.33 \\
Species level & 1.932 & 1.297 & 0.310 & 0.189 & 93.20 & 32 \\
\hline
\end{tabular}

A , observed number of alleles per locus; $A$ the effective number of alleles per locus; $\mathrm{H}$ Nei's (1973) gene diversity; I, Shannon's information index; PPB, percentage of polymorphic loci; PrB, private bands for population.
0.142. The lowest genetic distance was between populations SNG2 and SNG3 and the highest between populations SNG3 and NRN3.

A cluster tree of ISSR markers grouped the genotypes into two clusters (Fig. 2). The first cluster included populations NRN1, NRN2 and NRN3 and the second cluster populations SNG2, SNG3 and SNG4. Thus, ISSR primers were able to distinguish $H$. sangilense genotypes from different geographical areas.

Out of six primers screened, only three RAPD primers were selected to detect polymorphism based on reproducible banding patterns. In total, 51 bands were obtained, out of $21(40.6 \%)$ were polymorphic. The number of band per primer ranged from 13 to 20, with an average of 17 . The percentage of polymorphism detected with three RAPD primers was $41.2 \%$. Genetic similarity was calculated from Shannon's information and ranged from 0.065 to 0.268 , with a mean of 0.144 . Nei's (1973) gene diversity $(H)$ values within populations were 0.114 (range from 0.044 to 0.211 ) and 0.175 on the species level (Table 3).

Nei's (1978) genetic distance among populations ranged from 0.056 to 0.158 (Table 4). The lowest Nei's genetic distance value was calculated as 0.056 between populations SNG4 and NRN2, and the highest value was noted between populations NRN1 and NRN3 (0.158). The distance matrix was subjected to UPGMA clustering to generate a dendrogram, which separated $H$. sangilense genotypes into three clusters (Fig. 2).

Combining both markers, a total of 147 DNA fragments were produced, of which 51 (34.7\%) were polymorphic, with an average of 5.2 polymorphic fragments per primer. Genetic similarity was calculated from Shannon's information index for all 106 genotypes of the $H$. sangilense complex; combined RAPD and ISSR ranged from 0.099 to 0.336 , with a mean of 0.174. Mean Nei’s (1973) genetic diversity $(\mathrm{H})$ was 0.132 (range from 0.046 to 0.210 ); on the species level, it was 0.173. Nei's (1978) genetic distance range was from 0.053 to 0.156 . Two clusters were produced (Fig. 2) in patterns that more closely resembled the ISSR analysis compared to the RAPD analysis.

Combining both markers, genetic differentiation among populations at the species level (GST) was 0.383 , and gene flow among populations $\left(\mathrm{N}_{\mathrm{M}}\right)$ was 0.804 . The results 
of AMOVA point to higher levels of variation within populations (68\%) than between populations (38\%) (Table 5).

The result of the Mantel test with 999 permutations revealed a significant correlation between matrices of genetic distance and geographic distance $(r=0.668, \mathrm{P}=0.011)$.

In the PCA based on Nei's genetic distance matrix of genets, the first (PC1) and second (PC2) principal component axes accounted for 28.60 and $12.54 \%$ of the total variation, respectively (Fig. 3).

Table 4. Nei's (1978) unbiased estimates of genetic identity and genetic distance among populations of Hedysarum sangilense by improved RAPD and ISSR.

\begin{tabular}{lllllll}
\hline Population & NRN1 & NRN3 & NRN2 & SNG4 & SNG3 & SNG2 \\
\hline RAPD & & & & & & \\
NRN1 & & 0.854 & 0.866 & 0.909 & 0.924 & 0.941 \\
NRN3 & 0.158 & & 0.908 & 0.882 & 0.875 & 0.907 \\
NAR2 & 0.144 & 0.097 & & 0.945 & 0.933 & 0.882 \\
SNG4 & 0.095 & 0.125 & 0.056 & & 0.981 & 0.899 \\
SNG3 & 0.079 & 0.133 & 0.069 & 0.019 & & 0.903 \\
SNG2 & 0.061 & 0.098 & 0.125 & 0.106 & 0.102 & \\
ISSR & & & & & & \\
NRN1 & & 0.918 & 0.880 & 0.897 & 0.883 & 0.922 \\
NRN3 & 0.086 & & 0.904 & 0.886 & 0.868 & 0.927 \\
NAR2 & 0.128 & 0.100 & & 0.904 & 0.875 & 0.894 \\
SNG4 & 0.109 & 0.121 & 0.101 & & 0.923 & 0.924 \\
SNG3 & 0.124 & 0.142 & 0.133 & 0.080 & & 0.941 \\
SNG2 & 0.081 & 0.075 & 0.112 & 0.079 & 0.061 & \\
\hline GNic & & & & & &
\end{tabular}

Genetic similarity is listed above the diagonal and genetic distance is listed below the diagonal.

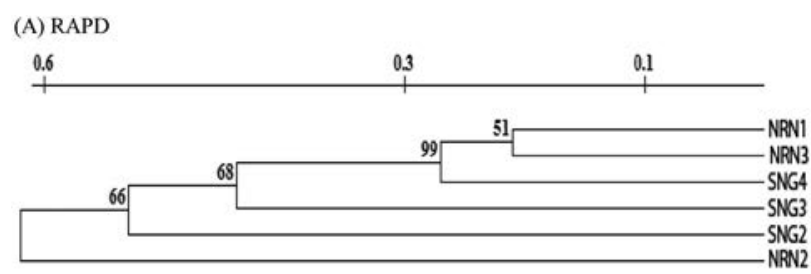

(B) ISSR

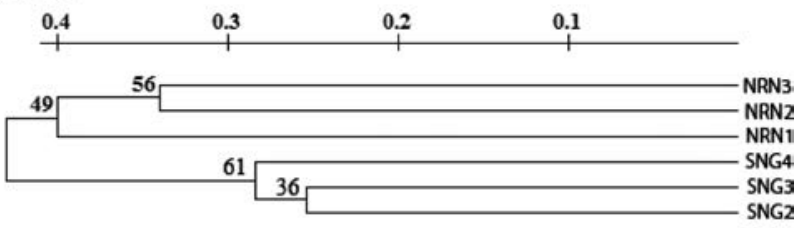

(C) RAPD + ISSR

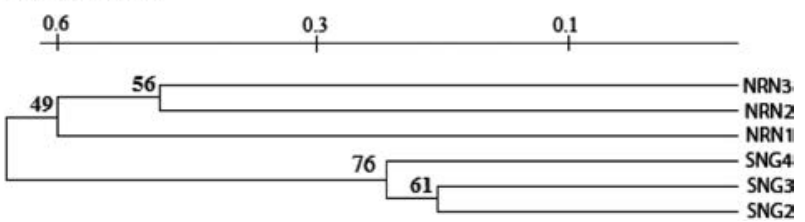

Figure 2 UPGMA dendrogram based on Nei's (1972) genetic distance using (a) RAPD (b) ISSR and (c) ISSR + RAPD data

\section{DISCUSSION}

Under changing environmental conditions, genetic diversity is crucial to effectively manage and conserve valuable, rare endemic species, such as $H$. sangilense. To understand the extent of genetic diversity, genetic structure and differentiation among $H$. sangilense populations occurring in different geographic regions, two PCR-based molecular markers, namely RAPD and ISSR, were used. The combined use of several markers types enables coverage of different parts of the genome and provides more informative data than the use of individual markers alone (Josiah et al. 2008).

In the present study, we show that these markers revealed a genetic variation among geographically separated sub-populations of $H$. sangilense. Inter-simple sequence repeats and RAPDs also revealed diversity within each population. The obtained results based on heterozygosity data for both the markers are in accordance with various studies in other wild plant species (Hien \& Phong 2012, Selyutina et al. 2014, 2016).

Endemic and narrowly distributed plants usually show lower levels of genetic diversity and higher levels of genetic structure compared with their relatives with wider distribution areas. This is probably caused by the more accentuated effects of genetic drift and restricted gene flow in the rarer plants (Hamrick \& Godt 1989, Nybom 2004). For the endemic $H$. sangilense, we revealed that whatever the mountain range or the population within a mountain range, most of the genetic diversity was found within populations. The same trend has commonly been reported for outcrossing and/or perennial species (Hamrick et al. 1992).

Hedysarum sangilense exhibits low levels of genetic diversity within populations (expected heterozygosity, $\mathrm{H}_{\mathrm{E}}=0.115$ ), which was lower than that of the average plant species with restricted distribution $\left(\mathrm{H}_{\mathrm{E}}=0.191\right)$, using RAPD markers (Nybom \& Bartish 2000). This conforms to the value $\left(\mathrm{H}_{\mathrm{E}}\right.$ $=0.20$ ) found by Nybom (2004) in a literature survey for endemic species, using dominant markers.

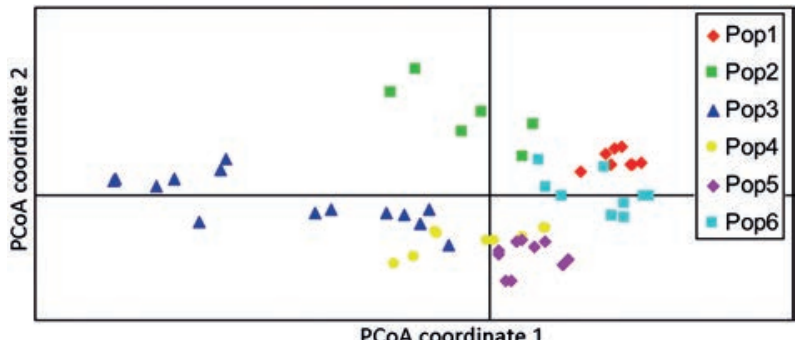

Figure 3 A two-dimensional plot of the PCA combine of RAPD and ISSR DNA markers data showing the clustering of populations of Hedysarum sangilense Krasnoborov et Timokhina The first and second principal coordinates account for $28.60 \%$ and $12.54 \%$ of total variation, respectively

Table 5. Analysis of molecular variance (AMOVA) within and among Hedysarum sangilense populations.

\begin{tabular}{lllllrr}
\hline Source of variation & $\begin{array}{l}\text { Degree of } \\
\text { freedom }\end{array}$ & Sum of squares & Mean squares & $\begin{array}{l}\text { Variance } \\
\text { component }\end{array}$ & Total variance (\%) P - value \\
\hline Among population & 6 & 369.91 & 61.65 & 4.81 & 38 & $<0.001$ \\
Within population & 72 & 557.96 & 7.75 & 7.75 & 62 & $<0.001$ \\
\hline
\end{tabular}


The genetic structure of plant populations reflects the interactions of various evolutionary processes, including the long-term evolutionary history, such as shifts in distribution, habitat fragmentation, population isolation, mutation, genetic drift, breeding system, gene flow and selection (Schaal et al. 1998). Factors such as isolation, small populations and gene flow may have a major influence on the levels of genetic diversity within and among populations (Hamrick et al. 1992). Comparisons with other studies are difficult since genetic diversity depends on numerous factors, such as life history, breeding system, growth life forms, geographical range and even the type of molecular method used (Powell et al. 1996, Nybom 2004). In spite of these complications, if we compare the results of studies using dominant markers, it appears that the genetic diversity of $H$. sangilense is lower than that of some other alpine species: Eryngium alpinum L. ( $\mathrm{H}_{\mathrm{E}}=0.20$; Gaudeul et al. 2000), Trollius europaeus L. $\left(\mathrm{H}_{\mathrm{E}}=0.22\right.$ in the Alps and 0.197 in the Pyrenees; Despres et al. 2002), Epilobium fleischeri Hochst., Geum reptans L. and Campanula thyrsoides L. $\left(\mathrm{H}_{\mathrm{E}}=0.19,0.21\right.$ and 0.20, respectively; Kuss et al. 2008) and Senecio boissieri DC. $\left(\mathrm{H}_{\mathrm{E}}=\right.$ 0.19 in the Cantabrian Mountains; Peredo et al. 2009).

Our analyses of genetic structure revealed a moderate differentiation among populations (GST $=0.383$ ). In a meta-analysis of RADP-based estimates of TST values, Nybom \& Bartish (2000) and Nybom (2004) demonstrated that ФST values are significantly related to life form, with long-lived perennials showing the lowest figures (mean 0.25) and species with a mixed-breeding system showing intermediate levels (means 0.25-0.4; Nybom \& Bartish 2000, Nybom 2004). Endemics do not differ from more widespread species in this respect.

The comparatively low levels of population differentiation imply that in $H$. sangilense, isolation may be less severe or has occurred much more recently. This is indicated by the overlap of populations in the PCA (Fig. 2) and by the AMOVA results. Most of the genetic variance remains within populations (68\%), a pattern often described for mountain plants (Gugerli et al. 1999, Wesche et al. 2006).

Pollen dispersal is a primary mechanism of gene flow over long distances in most entomophilous plants (Levin 1987). Because the foraging flights of bumblebees are often longer than $5 \mathrm{~km}$ (Heinrich 1978), of the low geographical differentiation and the weak effects on genetic distance observed in $H$. sangilense may be caused by frequent longdistance pollen flow. Pollen flow is likely to be responsible for gene flow among mountain ranges (Pluess \& Stocklin 2004), and cross-pollination and long-distance movement of pollen by pollinators could reduce genetic differentiation among populations (Ismail et al. 2012). Available out-crossing assures a minimum genetic flow among populations to weaken or even offset the effects of genetic drift (Bacchetta et al. 2011). As seeds are large (millimeters) and likely to be dispersed by gravity in this species, frequent gene flow via seed dispersal is considered unlikely.

The primary objective in nature conservation is to preserve as much as possible of the evolutionary potential of species through maintaining the main part of genetic diversity.
Knowledge of the genetic variation between and within populations of rare and endangered species plays a significant role in the formulation of appropriate management strategies directed towards their conservation (Milligan et al. 1994, Wallace 2002).

\section{CONCLUSIONS}

Our findings provide important genetic information for developing conservation strategies for $H$. sangilense. There is an urgent need to take effective measures to protect this species against further loss of genetic diversity; more attention should be placed on the restoration of suitable habitats and on the effective population size.

\section{ACKNOWLEDGEMENTS}

The research was carried out within the framework of the state task No. AAAAA 21-121011100007-6 of the Central Siberian Botanical Garden of the Siberian Branch of the Russian Academy of Sciences.

\section{I T E R A T URE CITED}

Alexander, J.A., A. Liston \& S. J. Popovich 2004. Genetic diversity of the narrow endemic Astragalus oniciformis (Fabaceae). American Journal of Botany 91(12):2004-2012.

Bacchetta, G., G. Fenu, E. Mattana, G. Zecca, F. Grassi, G. Casazza \& L. Minuto 2011. Genetic variability of the narrow endemic Rhamnus persicifolia Moris (Rhamnaceae) and its implications for conservation. Biochemical Systematic and Ecology 39:477-484.

Barrett, S.C.H. \& J.R. Kohn. 1991. Genetic and evolutionary consequences of small population size in plants: implications for conservation. In: Genetics and conservation of rare plants (D.A Falk \& K.E. Holsinger, eds.), pp. 3-30, Oxford University Press, Oxford, UK.

Baskauf, C.J. \& S. Snapp 1998. Population genetics of the cedar-glade endemic Astragalus bibullatus (Fabaceae) using isozymes. Annals of the Missouri Botanical Garden 85(1):90-96.

Bauert, M.R., M. Kalin, M. Baltisberger, \& P.J. Edwards 1998. No genetic variation detected within isolated relict populations of Saxifraga cernua in the Alps use RAPD markers. Molecular Ecology 7:1519-1527.

Booy, G., R.J.J. Hendriks, M.J.M. Smulders, J.M. Van Groenendael \& B. Vosman 2000. Genetic diversity and the survival of populations. Plant Biology 2(4):379-395.

Cires, E., C. Cuesta \& J.A. Fernandez Prieto 2013. Genetic diversity and structure in fragmented populations of the endangered species Ranunculus cabrerensis (Ranunculaceae): implication for conservation. Biologia 68(1):30-40.

Dauber, J., J.C. Biesmeijer, D. Gabriel, W.E. Kunin, E. Lamborn, B. Meyer, A. Nielsen, S.G. Potts, S.P.M. Roberts, V. Sober, J. Settele, I. Steffan-Dewenter, J.C. Stout, T. Teder, T. Tscheulin, D. Vivarelli \& T. Petanidou 2010. Effects of patch size and density on flower visitation and seed set of wild plants: a pan-European approach. Journal of Ecology 98(1):188-196.

Despres, L., S. Loriot \& M. Gaudeul 2002. Geographic pattern of genetic variation in the European globeflower Trollius europaeus L. (Ranunculaceae) inferred from amplified fragment length polymorphism markers. Molecular Ecology 11:2337-2347.

Doyle, J.J. \& J.L. Doyle 1987. A rapid DNA isolation of fresh leaf tissue. Phytochemical Bulletin 19(1):11-15. 
Dudash, M.R. \& C.B. Fenster 2000. Inbreeding and outbreeding depression in fragmented populations. In: Genetics, demography and viability of fragmented populations (A.G. Young \& G.M. Clarc, eds.), pp. 35-53, Cambridge University Press, Cambridge.

Edwards, A.L. \& R.R. Sharitz 2000. Population genetics of two rare perennials in isolated wetlands: Sagittaria isoetiformis and S. teres (Alismataceae). American Journal of Botany 87(8):1147-1158.

Ellstrand, N.C. \& D.R. Elam 1993. Population genetic consequences of small population size: implications for plant conservation. Annual Review of Ecology, Evolution, and Systematics 24: 217-242.

Escaravage, N., J. Cambecedes, G. Largier \& A. Pornon 2011. Conservation genetics of the rare Pyreneo-Contabrian endemic Aster pyrenaeus (Asteraceae). AoB Plants 2011:plr029.

Esselman, E. J., L. Jianqiang, D.J. Crawford, J.L. Windus \& A.D. Wolfe 1999. Clonal diversity in the rare Calamgrositis porteri subsp. isperata (Poaceae): comparative results for allozymes and random amplified polymorphic DNA (RAPD) and intersimple sequence repeat (ISSR) markers. Molecular Ecology 8(3):443-451.

Falk, D.A. \& K.E. Holsinger 1991. Genetic and conservation of rare plants. Oxford University Press, Ney York, 361 pp.

Frankham, R., J.D. Ballou \& D.A. Briscoe 2002. Introduction to conservation genetics. Cambridge. Cambridge University Press, 617 pp.

Gitzendanner, M.A. \& P.S. Soltis 2000. Patterns of genetic variation in rare and widespread congeners. American Journal of Botany 87(6):783-792.

Gaudeul, M, I. Till-Bottraud, F. Barjon \& S. Manel 2004. Genetic diversity and differentiation in Eryngium alpinum L. (Apiaceae): comparison of AFLP and microsatellite markers. Heredity 92:508-518.

Gunin, P.D., E.A. Vostokova, N.I. Dorofeyuk, P.E. Tarasova \& C.C. Black 1999. Vegetation dynamics of Mongolia. (Geobotany 26). Kluwer Academic Publishers. Dordrecht. 238 pp.

Gugerli, F., K. Eichenberger \& J.J. Schneller 1999. Promiscuity in populations of the cushion plant Saxifraga oppositifolia in the Swiss Alps as inferred from RAPDs. Molecular Ecology 8:453-461.

Hamrick, J.L. \& J.W. Godt 1989. Allozyme diversity in plant species. In: Plant population genetics, breeding, and genetic resources (A.H.D. Brown, M.T. Clegg, A.L. Kahler \& B.S. Weir, eds), pp. 43-63, Sinauer, Sunderland, MA.

Hamrick, J.L., M.J.W. Godt \& S.L. Sherman-Broyles 1992. Factors influencing levels of genetic diversity in woody plant species. New Forests 6:95-124.

Hamrick, J.L. \& M.J.W. Godt 1996. Effects of life history traits on genetic diversity in plant species. Philosophical Transactions of the Royal Society B: Biological Sciences 351: 1291-1298.

Heinrich, B. \& G.A. Bartholomew 1978. Roles of endothermy and size in inter- and intraspecific competition for elephant dung in an African dung beetle, Scarabaeus laevistriatus. Physiological Zoology 52:484-494.

Holsinger, K.E. \& P. Vitt 1997. The future of conservation biology: what's a geneticist to do? In: Enhancing the ecological basis of conservation: heterogeneity, ecosystem function, and biodiversity (S.T.A. Pickett, R.S. Ostefeld, M. Shachak \& G.E. Likens, eds), pp. 206-216, Chapman \& Hall, New York.

Hien,V.T.T \& D.T. Phong 2012. Genetic diversity among endangered rare Dalbergia cochinchinensis (Fabaceae) ge- notypes in Vietnam revealed by random amplified polymorphic DNA (RAPD) and inter simple sequence repeats (ISSR) markers. African Journal of Biotechnology 11(35):8632-8644.

Hughes, A.R., B.D. Inouye, M.T.J. Johnson, N. Underwood \& M. Vellend 2008. Ecological consequences of genetic diversity. Ecology Letters 11(6):609-623.

Ismail, S.A., J. Ghazoul, G. Ravikanth, R. Uma Shaanker, C.G. Kushalappa \& C.J. Kettle 2012. Does long-distance pollen dispersal preclude inbreeding in tropical trees? Fragmentation genetics of Dysoxylum malabaricum in an agro-forest landscape. Molecular Ecology 21:5484-5496.

Josiah C.C., D.O. George, O.M Eleazar \& W.F. Nyamu 2008. Genetic diversity in Kenyan populations of Acacia senegal (L.) willd revealed by combined RAPD and ISSR markers. African Journal of Biotechnology 7(14):2333-2340.

Kalisz, S., F.M. Hanzawa, S.J. Tonsor, D.A. Thiede \& S. Voigt 1999. Ant-mediated seed dispersal alters pattern of relatedness in a population of Trillium grandiflorum. Ecology 80: 2620-2634.

Krasnikov, A. \& D. Schaulo 2004. Karyoiogical study of the Tuva Republic flora: summary. Turczaninowia 7(2):82-95 (in Russian). [Красников А., А. Шауло 2004. Кариологическое изучение флоры республики Тува: некоторые итоги // Turczaninowia. T.7, №2. C. 85-92].

Krasnoborov, I.M \&. S.A. Timochina 1975. A new species of Hedysarum L. from the Tuva ASSR. Novitates Systematicae Plantarum Vascularum 12:234-237 (in Russian). [Красноборов И.М., Тимохина С.А 1975. Новый виА Hedysarum L. из Тувинской АССР // Новости систематики высших растений. №12. С. 234-237].

Kunin, W.E. 1997. Population size and density effects in pollination: pollinator foraging and plant reproductive success in experimental arrays of Brassica kaber. Journal of Ecology 85:225-234.

Kurbatskii, V.I. 1994. Hedysarum L. In: Flora of Siberia, vol. 9 (A.V. Polozhii \& L.I. Malyshev, eds), pp. 153-166, Nauka, Novosibirsk (in Russian). [Курбатский В.И. 1994. Hedysarum L. - Копеечник // ФАора Сибири / поА реА. А.В. Положий и А.И. Малышева. Новосибирск: Наука. Т. 9. С. 153-166].

Kuss P, A.R. Pluess, H.H. Egisdottir \& J. Stöcklin 2008. Spatial isolation and genetic differentiation in naturally fragmented plant populations of the Swiss Alps. Journal of Plant Ecology 1:149-159.

Lazaro, A., R. Lundgren \& O. Totland 2009. Co-flowering neighbors influence the diversity and identity of pollinator groups visiting plant species. Oikos 118(5):691-702.

Levin, D.A. 1987. Local differentiation and the breeding structure of plant populations. In: Plant evolutionary biology (L.D. Gottlieb \& S.K. Jain, eds), pp. 305-329, Chapman \& Hall: London.

Lewinton, R.C. 1972. The apportionment of human diversity. Evolutionary Biology 6:381-398.

Loveless, M.D. \& J.L. Hamrick 1984. Ecological determinations of genetic structure in plant populations. Annual Review of Ecology, Evolution, and Systematics 15:65-95.

Malyshev, L.I. \& K.A. Sobolevskaya (eds) 1980. Rare and endangered plants of Siberia, Nauka, Novosibirsk, 223 pp. (in Russian). [Редкие и исчезающие растения Сибири / под ред. А.И. Малышева и К.А. Соболевской. Новосибирск: Наука. 223 с.]. 
Matties, D., I. Brauer, W. Maibom \& T. Tscharntke 2004. Population size and the risk of local extinction: empirical evidence from rare plants. Oikos 105:481-488.

McGlaughlin, M., K. Karoly \& T. Kaye 2002. Genetic variation and its relationship to population size in reintroduced populations of pink sand verbena, Abronia umbellate subsp. breviflora (Nyctaginaceae). Conservation Genetics 3(4): 411-420.

Milligan, B.G., J. Leebens-Mack \& A.E. Strand 1994. Conservation genetics: beyond the maintenance of marker diversity. Molecular Ecology 3(4):423-435.

Neel, M.C. 2008. Patch connectivity and genetic diversity conservation in the federally endangered and narrowly endemic plant species Astragalus albens (Fabaceae). Biological Conservation 141(4): 938-955.

Nei, M. 1972. Analysis of gene diversity in subdivided populations. Proceeding of the National Academy of Science of the USA 70(12):3321-3323.

Nybom, H. \& I.V. Bartish 2000. Effects of life history traits and sampling strategies on genetic diversity estimates obtained with RAPD markers in plant. Perspective in Plant Ecology, Evolution and Systematics 3(2):93-114.

Nybom, H. 2004. Comparison of different nuclear DNA markers for estimating intraspecific genetic diversity in plants. Molecular Ecology 13:1143-1155.

Oostermeijer, J.G.B., S.H. Luijten, \& J.C.M. den Nijs 2003. Integration demographic and genetic approaches in plant conservation. Biological Conservation 113:389-398.

Oliva-Tejera, F., J. Caujapé-Castells, J. Naranjo-Suárez, J. Navarro-Déniz, J.R. Acebes-Ginovés \& D. Bramwell 2005. Population genetic differentiation in taxa of Lotus (Fabaceae: Loteae) endemic to the Gran Canarian pine forest. Heredity 94(2):199-206.

Peakall, R \& P. Smouse 2012. GenAlEx 6.5: genetic analysis in Excel. Population genetic software for teaching and research - an update. Bioinformatics 28:2537-2539.

Peredo, E.L., M.A. Revila, B. Jimenez-Alfaro, A. Bueno, J.A.F. Prieto \& R.J. Abbott 2009. Historical biogeography of a disjunctly distributed, Spanish alpine plant, Senecio boissieri (Asteraceae). Taxon 58:1-10.

Pluess, A.R., \& J. Stocklin 2004. Population genetic diversity of the clonal plant Geum reptans (Rosaceae) in the Swiss Alps. American Journal of Botany 91:2013-2021.

Rathcke, B.J. \& E.S. Jules 1993. Habitat fragmentation and plant-pollinator interactions. Current Science 65:273-277.

Rogenski, C. \& M. Smith, E. Esselman 2009. ISSR marker diversity of the threatened Astragalus crassicarpus var. trichocalyx in Illinois populations. Transactions of the Illinois State Academy of Science 102 (3/4):149-159.

Schaal B.A, D.A. Hayworth, K.M. Olsen, J.T. Rauscher \& W.A. Smith 1998. Phylogeographic studies in plants: problems and prospects. Molecular Ecology 7:465-474.

Selyutina, I.Yu., E.S. Konichenko \& O.V. Dorogina 2014. The possibility of using of ISSR-markers for detection of genetic differentiation of populations of rare species Astragalus sericeocanus (Fabaceae). Rastitel'nyi Mir Aziatskoi Rossii 4:3-8 (in Russian). [Селютина И.Ю., Коничен- ко Е.С., Аорогина О.В. 2014. Возможности использования ISSR-маркеров Аля выяв ения генетической Аифференциации популяций редкого вида Astragalus sericeocanus (Fabaceae) 2014 // Растительный мир Азиатской России №4(16). С. 3-8.]

Selyutina, I.Yu., E.S. Konichenko, O.V. Dorogina \& D.V. Sandanov 2016. Genetic diversity of the endangered endemic milkvetch Astragalus sericeocanus Gontsch., Fabaceae, from the Lake Baikal region. Biochemical Systematics and Ecology 63: 163-169.

Schonswetter, P., A. Tribsch, M. Barfuss \& H. Niklfeld 2002. Several Pleistocene refugia detected in the high alpine plant Phyteuma globulariifolium in the Europian Alps. Molecular Ecology 11:2637-2647.

Schonswetter, P., A. Tribsch \& H. Niklfeld 2004. Amplified Fragment Length Polymorphism (AFLP) reveals no genetic divergence of the Eastern Alpine endemic Oxytropis campestris subs. tiroliensis (Fabaceae) from widespread subs. campestris. Plant Systematics and Evolution 244(3):245-255.

Slatkin, M. 1985. Gene flow in natural populations. Annual Review of Ecology, Evolution, and Systematics 16:393-430.

Slatkin, M. 1987. Gene flow and the geographic structure of natural populations. Science 236:787-792.

Travis, S.E., J. Maschinski \& P. Keim 1996. An analysis of genetic variation in Astragalus cremnophylax var. cremnophylax, a critically endangered plant, using AFLP markers. Molecular Ecology 5(6):735-745.

Urgamal, M., B. Oyuntsetseg, D. Nyambayar \& Ch. Dulamsuren. 2014. Conspectus of the vascular plants of Mongolia. Admon Printing, Ulaanbaatar, Mongolia, 282 pp.

Van Dyke, F. 2008. Conservation biology: foundations, concepts, applications. 2nd edition. Springer, Berlin, 614 pp.

Vicente, M.J., F. Segura, M. Aguado, D. Migliaro, J.J. Franco \& J.J. Martínez-Sánchez 2011. Genetic diversity of Astragalus nitidiflorus, a critically endangered endemic of SE Spain, and implications for its conservation. Biochemical Systematics and Ecology 39:175-182.

Wallace, L.E. 2002. Examining the effects of fragmentation on genetic variation in Platanthera leucophaea (Orchidaceae): inference from allozyme and random amplified polymorphic DNA markers. Plant Species Biology 17:37-49.

Wesche, K., I. Hensen \& R. Undrakh 2006. Genetic structure of Galitrkya macrocarpa and G. potaninii, two closely related endemics of Central mountain ranges. Annals of Botany 98:1025-1034.

Wilcock, C. \& R. Neiland 2002. Pollination failure in plants: why it happens and when it matters. Trends in Plant Science 7(6): 270-277.

Yeh, F.C., R.C. Yang, T.B.J. Boyle Z.H. Ye \& J.X. Mao 1997. Popgene: the user friendly shareware for population genetic analysis. Molecular Biology and Biotechnology Center, University of Alberta, Edmonton.

Zhang, Z., S. Chen, S. Chen \& Q. Gao 2007. Patterns of genetic variation in Swertia præewalskii, an endangered endemic species of the Qinghai-Tibet Plateau. Biochemical Genetics 45(1-2):33-50. 